\title{
POSSIBILITIES OF VAGINAL BIOTOPE CORRECTION IN PREGNANT WOMEN AFTER ASSISTED REPRODUCTIVE TECHNOLOGIES
}

L.M. VYGIVSKA

PhD, assistant professor, Obstetrics and Gynecology Department №. 3, Bogomolets National

Medical University, Kyiv

ORCID: 0000-0001-8939-2239

\section{V.O. BENIUK}

MD, professor, head of the Obstetrics and Gynecology Department №. 3, Bogomolets National

Medical University, Kyiv

ORCID: 0000-0002-5984-3307

I.V. MAIDANNYK

$\mathrm{PhD}$, assistant professor, Obstetrics and Gynecology Department No. 3

Bogomolets National

Medical University, Kyiv

ORCID: 0000-0003-0849-0406

\section{I.A. USEVYCH}

PhD, assistant professor, Obstetrics and Gynecology Department No. 3,

Bogomolets National

Medical University, Kyiv

ORCID: 0000-0001-5200-8184

\section{L.D. LASTOVETSKA}

PhD, assistant professor, Obstetrics and Gynecology Department No. 3

Bogomolets National

Medical University, Kyiv

ORCID: 0000-0002-1085-6457

Y.G. DRUPP

PhD, assistant professor, Obstetrics and Gynecology Department No. 3,

Bogomolets National

Medical University, Kyiv

ORCID: 0000-0001-6179-9141

V.V. KUROCHKA

$\mathrm{PhD}$, assistant, Obstetrics and

Gynecology Department No. 3,

Bogomolets National

Medical University, Kyiv

ORCID: 0000-0001-6800-310X

\section{CONTACTS}

IgorV. Maidannyk

Bogomolets National Medical

University, Obstetrics and Gynecology

Department No. 3

V. Kuchera str. 7

03148, Kyiv, Ukraine

Tel.: + 38 (096) 5040303

Email:saman@yandex.ua

\section{INTRODUCTION}

The issue of preserving the reproductive health of the nation in Ukraine is acute [2]. The leading factors that negatively affect its formation are the rapid decline in birth rates, the growing number of people of reproductive age with severe somatic and obstetric pathology, prolonged stress associated with the socio-economic crisis and hostilities in eastern Ukraine, and high density of complicated pregnancy and childbirth course [1, 9, 12-14].

From this point of view, couples with infertility deserve special attention, as there are almost 1 million of these couples in the country today, which is $6.8 \%$ of the total number of married couples [15]. According to the results of recent studies, in 2016 alone, 38,998 cases of female and 11,210 cases of male infertility were registered in Ukraine $(77.7 \%$ and $22.3 \%$, respectively, in the structure of total infertility) [15]. The growing trend of infertility in marriage is inherent in the population of countries around the world, which led to a rapid search for new methods of treatment $[16,18]$.

In recent years, in the general population of pregnant women, we see an increase in density of women whose pregnancies are the result of use of assisted reproductive technologies (ART). Modern authors rightly consider ART as one of the most promising and effective methods of infertility treatment, which is used in Ukraine as well more and more every year [15].

The introduction of ART in the daily practice of infertility treatment has improved demographic indicators and increased the birth rate in Ukraine in recent years by fourfold. At the same time, pregnancies resulting from the use of ART usually have a high risk of aggravated course with the development of mostly placental-associated complications: miscarriage and prematurity, preeclampsia, fetal growth retardation (fetal growth) and fetal distress $[10,22,24,26]$.

Of particular importance for the prolongation of pregnancy and the normal course of labor is the state of the vagina biocenosis $[1,3,11,19,20,25]$. Changes in the vaginal biotope in pregnant women after the use of ART, which is characterized by the persistence of associative pathogens, play a leading role in the genesis of unfavorable course of pregnancy and the manifestation of its termination $[1,23]$. That is why one of the tasks of our study was to develop a comprehensive pathogenetically determined approach to the lavage of lesions in the vagina to improve pregnancy and perinatal consequences.

Research objective: to determine the role and effectiveness of proposed treatment and prevention complex for correction of the vaginal biocenosis disorders in the pregnancy dynamics in women after ART to improve the tactics of antenatal care and prevention of obstetric and perinatal complications.

\section{MATERIALS AND METHODS}

A prospective clinical examination of 299 pregnant women was conducted. Main group included 249 women whose pregnancy occurred as a result of ART, control group consisted of 50 pregnant women with spontaneous pregnancy and its physiological course, who were registered in antenatal clinic in 6-8 weeks of gestation.

Women of the main group are divided into subgroups depending on therapy and cause of infertility: - subgroup I - pregnant women with tubalperitoneal type of infertility in anamnesis;

- subgroup II - pregnant women with endocrine type of infertility in anamnesis;

- subgroup III - pregnant women with a history of male infertility.

Pregnant women were further divided within the group into subgroups $A$ and $B$. Letter $A$ in a title of subgroup means that women received the proposed treatment and prevention complex and psycho-emotional correction complex; letter $B$ indicated that pregnant women were observed in accordance with generally accepted standards of obstetric care regulated by orders of the Ministry of Health of Ukraine. Subgroup IA included 49 women, subgroup IB - 45 patients, subgroup IIA -48 , subgroup IIB -39 , subgroup IIIA -36 and subgroup IIIB - 32 women. Pregnant women were representative by age, family and social status, place of residence, which allowed us to further evaluate the differences caused precisely by the etiological factors of infertility.

All pregnant women were examined in accordance with the quality standards of the orders of the Ministry of Health of Ukraine No. 417 "Methodological recommendations for providing outpatient obstetric and gynecological care" from 15.07.2011 [4], No. 787 "The procedure for using ART in Ukraine" from 09.09.2013 [5].

CITOLAB diagnostic test strips (Pharmasco, Ukraine) were used to measure the acidity of the 
vaginal environment $(\mathrm{pH})$. The degree of vaginal purity and number of leukocytes were assessed by microscopic examination. Impressions of the material were applied to glass, stained by Gram and methylene blue [3].

The amine test was performed to determine one of the diagnostic criteria for bacterial vaginosis. Results were evaluated by the semi-quantitative method proposed in 1995 by E.F. Kira [17]: $1+$ is a typical "fishy smell" appears only when mixing secretions with $10 \% \mathrm{KOH}$ solution; $2+$ is secretions have a moderate odor, which is enhanced by the addition of $10 \%$ solution of $\mathrm{KOH} ; 3+$ is the expressed smell of secretions that considerably amplifies if $10 \% \mathrm{KOH}$ solution is added. A positive amine test was considered a diagnostic criterion for bacterial vaginosis. Laboratory diagnosis was performed by microscopic method with subsequent counting of "key cells".

Microbiological researches and the account of results were carried out according to the order No. 234 of the Ministry of Health of Ukraine from 10.05.2007 [6].

Blood agar, yellow-salt agar, Endo and Sabouraud agar, MRS agar for lactobacilli were used for seeding mucus [21]. Further identification of microorganisms was performed on an automatic microbiological analyzer BD BBL, Crystal (USA) [19].

The recommended complex of therapeutic and preventive measures for pregnant women after ART is:

1. Progesterone support (micronized progesterone orally and vaginally $200-400$ mg twice a day) up to 12 weeks, followed by adjustment of the dosage depending on the clinical picture of pregnancy.

2. Magnesium saturation (magnesium oxide light $342 \mathrm{mg}$ and magnesium carbonate light $670 \mathrm{mg}$, which corresponds to magnesium ions $365 \mathrm{mg}, 1$ tablet once a day during pregnancy).

3. Folic acid $200 \mu \mathrm{g}$ and metafolin $200 \mu \mathrm{g}, 1$ tablet once a day orally with a meal before pregnancy and during the first 16 weeks of pregnancy.

4. L-arginine aspartate oral solution $5 \mathrm{ml}(1 \mathrm{ml}$ of solution contains $200 \mathrm{mg}$ of L-arginine aspartate) 3 times a day from the 8th week of pregnancy to the 16th week of pregnancy $[5,14]$.

5. Omega-3 polyunsaturated fatty acids 1 capsule three times a day starting from the 12 th week of pregnancy.

6. Local rehabilitation of the genital tract in accordance with the Order of the Ministry of Health of Ukraine from 27.12.2006 No. 906 "Perinatal infections" [7] if there was an infection of the genital tract in pregnant women after ART. Antibacterial drug was chosen taking into account the sensitivity to antibiotics of certain microbial associates and prescribed for 7 to 10 days.

In the second stage of rehabilitation of the genital tract (under $\mathrm{pH}$ control indicator test strips) specific biological drugs probiotics were prescribed for long-term maintenance of the acidic environment of vaginal contents ( $\mathrm{pH}=4.0-4.4)$, ensuring the colonization of the vagina and vaginal part of the cervix by lactobacilli, which provide key mechanisms of normobiocenosis and have a beneficial effect on pregnancy. Due to the fact that most probiotics used to restore the biotope of the vagina contain strains of bifidobacterium and lactobacilli of intestinal origin with weak adhesive activity against vaginal epitheliocytes, they are not able to stay long in their atypical vaginal environment.

Based on this, to restore the microbiocenosis of the vagina pregnant women after ART were prescribed vaginal capsules containing strains of Lactobacillus rhamnosus GR-1TM and Lactobacillus reuteri RC-14TM (one capsule before sleep for 7 day). Our choice was made due to the fact that, in addition to live active bacteria, but in a much higher concentration (at least $2 \times 10^{9}$ live bacteria) 1 capsule of the drug also contains fructooligosaccharides and lactic acid. The presence of a nutritious substrate for lactobacilli - fructooligosaccharides ensures the activity of lactobacilli, while lactic acid lowers the $\mathrm{pH}$ of the vaginal environment $(\mathrm{pH}=3.8-4.5)$, inhibiting the growth and adhesion of pathogenic associates and restoring the biotope of the vagina. Lactobacillus rhamnosus GR-1TM and Lactobacillus reuteri RC-14TM produce bactericides, as well as they have a pronounced anti-Gram-positive and anti-Gram-negative activity, destroy biofilms of pathogenic microorganisms. After 7-10 days, in order to maintain longterm acidity of the vaginal contents in the range of $\mathrm{pH} 3.9-$ 4.4 and restore the intestinal microflora, all pregnant women of the main group II were prescribed oral drug containing Lactobacillus rhamnosus GR-1TM $10 \mathrm{mg}(9.00-11.00 \mathrm{mg})$ and Lactobacillus reuteri RC-14TM $41 \mathrm{mg}$ (36.90-45.10 mg) 2 capsules with meals for a period of a month.

Statistical processing of the obtained results was analyzed with methods of descriptive and variational statistics using Student's criterion and Fisher angular transformation method. The results were calculated using Statistica program for Windows and Microsoft Excel 2016 program. Discrepancies were determined as possible at $p<0.05$.

The study was approved by the Commission on Bioethical Expertise and Ethics of Scientific Research at the O.O. Bogomolets National Medical University (protocol No. 118, January 18, 2019).

All participants signed an informed consent to participate in the study prior to the survey.

\section{RESULTS OF THE STUDY AND DISCUSSION}

On the background of improved therapy among pregnant in IA, IIA and IIIA subgroups, who received pathogenetically determined vaginal rehabilitation, there was a significant increase in the proportion of individuals with physiological $\mathrm{pH}$ (Table 1). The average $\mathrm{pH}$ values determining by test strips in these groups ranged from 4.0 to 4.6 , and the average value was $4.4 \pm 0.2$ in subgroup IA, $4.2 \pm 0.3$ in subgroup IIA and $4.0 \pm 0.1$ in subgroup IIIA, which corresponds to the normocenosis of the vaginal biotope. On the background of use of vaginal capsules with probiotic ( 1 capsule per night for 7 days) followed by an oral probiotic ( 2 capsules with a meal), the vast majority of pregnant women who received this complex in the control pH evaluation, in the dynamics of antenatal observation, marked persistence of weakly acidic environment.

In IB, IIB and IIIB subgroups the first stage of therapy with anti-inflammatory and antimicrobial topical drugs, which were prescribed taking into account the sensitivity to microbial pathogens-associates, was also characterized by normalization of the vaginal environment with registration of physiological $\mathrm{pH}$ values. The average $\mathrm{pH}$ was $4.5 \pm 0.4$ in subgroup IB, $4.6 \pm 0.2$ in subgroup IIB and $4.4 \pm 0.4$ in subgroup IIIB, and the maximum pathological $\mathrm{pH}$ values did not exceed the color standard of the test strips, which corresponds to $\mathrm{pH}$ 5.0. 
The fundamental fact is that in every second pregnant woman who received conventional therapy, on average $14 \pm 2$ days after the end of the vaginal lavage, $\mathrm{pH}$ of the vaginal contents shifted to alkaline and ranged from 4.7 to 5.5 , which is a diagnostic indicator of microbial contamination.

The efficacy of the proposed approach to the vaginal lavage in pregnant women after ART is shown in Tables 1-3.

In the main groups we noted a significant decrease in the proportion of individuals with a large number of epithelial cells (subgroup IA - 12 (24.5\%), subgroup IB - 24 (53.3\%); $p<0.05$, subgroup IIA $-8(16.7 \%)$, subgroup IIB $-16(41.0 \%)$; $p<0.05$, subgroup IIIA $-6(16.7 \%)$, subgroup IIIB $-10(31.2 \%)$; $p<0,05)$. This is a sign of alternative inflammation, which coincides with a similar indicator in the control group. In IB, IIB and IIIB subgroups were dominated by women with moderate (up to 10 in the field of view) leukocyte content and mixed Gram-negative microflora (subgroup IA - 38 (77.6\%), subgroup IB - $12(26.7 \%), p<0.05$; subgroup IIA 36 (75.0\%), subgroup IIB - $16(41.0 \%) ; p<0.05$; subgroup IIIB - 26 (72.2\%), subgroup IIIB - 20 (62.5\%); $p>0.05)$. In IIIA and IIIB subgroups there was no significant difference (subgroup IIIA - 26 (72.2\%), subgroup IIIB - 20 (62.5\%); $p>0.05)$.

Control examination of pregnant in IA, IIA and IIIA subgroups shows a significant predominance among the examined pregnant women (Table 1) of persons with the number of leukocytes, which corresponds to I-II degree of purity of the vaginal smear according to Heurlin (subgroup IA: single - $11(22.4 \%)$, up to 10 in the field of view - 38 (77.6\%); $p<0.05$; subgroup IIA: single $-12(25.0 \%)$, up to 10 in the field of view $-36(75.0 \%) ; p<0.05$, subgroup IIIA: single $-10(27.8 \%)$, up to 10 in the field of view $-26(72.2 \%)$; $p<0.05$;). In the dynamics of treatment we saw a significant decrease of the proportion of women with laboratory signs of aggravation of urogenital candidiasis in these subgroups (subgroup IA - 11 (22.4\%), subgroup IB - 22 (48.9\%), $p<0.05$, subgroup IIA - $10(20.8 \%)$, subgroup IIB - $17(43.6 \%)$; $p<0.05$; subgroup IIIA - 4 (11.1\%), subgroup IIIB - $6(18.8 \%)$; $p<0.05)$ and nonspecific inflammation, the leading role in its manifestation is played by conditionally pathogenic aerobic and anaerobic microorganisms (Table 2).

On the background of advanced therapy with probiotics of local and general action, in the dynamics of treatment of the vaginal biocenosis in IA, IIA and IIIA subgroups, content of Lactobacillus spp. significantly increased (subgroup IA - 29 (59.2\%), subgroup IB - $13(28.9 \%), p<0.05$; subgroup IIA 30 (62.5\%), subgroup IIB - 14 (35.9\%); $p<0.05$; subgroup IIIA - 26 (72.2\%), subgroup IIIB - 18 (56.3\%); $p<0.05)$. The average concentration of Lactobacillus spp. was significantly different from the average one in subgroups who received conventional therapy for vaginal lavage (subgroup IA Ig $4.34 \pm 0.2 \mathrm{CFU} / \mathrm{ml}$, subgroup IB $-\lg 3.40 \pm 0.42 \mathrm{CFU} / \mathrm{ml}$; $\mathrm{p}<0.05$; subgroup IIA - Ig $4.54 \pm 0.3 \mathrm{CFU} / \mathrm{ml}$, subgroup IIB Ig $3.51 \pm 0.4 \mathrm{CFU} / \mathrm{ml} ; \mathrm{p}<0.05)$ with a significant decrease of opportunistic aerobic and anaerobic microorganisms and Candida albicans in the biocenosis (subgroup IA - Ig $3.1 \pm 0.2$ $\mathrm{CFU} / \mathrm{ml}$, subgroup IB $-\lg 6.2 \pm 0.3 \mathrm{CFU} / \mathrm{ml}, \mathrm{p}<0.05$, subgroup IIA - Ig $3.0 \pm 0.3 \mathrm{CFU} / \mathrm{ml}$, subgroup IIB $-\lg 5.6 \pm 0.4 \mathrm{CFU} / \mathrm{ml}$, $p<0.05$, subgroup IIIA - Ig $3.2 \pm 0.4 \mathrm{CFU} / \mathrm{ml}$, subgroup IIIB lg $4.1 \pm 0.3 \mathrm{CFU} / \mathrm{ml}, \mathrm{p}<0.05$ ) (Table 3 ). This is indicates the effectiveness of the proposed two-stage treatment and provides favorable conditions for prolongation of pregnancy in women after ART.

\section{CONCLUSIONS}

Proposed improved two-stage sanitation of the genital tract method with a selective probiotic on the background of long-term progesterone and magnesium support

Table 1. Results of microscopy of vaginal discharge in the study groups, $n(\%)$

\begin{tabular}{|c|c|c|c|c|c|c|c|}
\hline \multirow{3}{*}{$\begin{array}{l}\text { Indicators of microscopy of } \\
\text { vaginal discharge }\end{array}$} & \multicolumn{6}{|c|}{ Main group $(n=249$ ) } & \multirow{3}{*}{$\begin{array}{c}\text { Control } \\
\text { group } \\
(n=50)\end{array}$} \\
\hline & \multicolumn{2}{|c|}{ I group $(n=94)$} & \multicolumn{2}{|c|}{11 group $(n=87)$} & \multicolumn{2}{|c|}{ III group $(n=68)$} & \\
\hline & $\begin{array}{l}\text { subgroup IA } \\
(\mathrm{n}=49)\end{array}$ & $\begin{array}{l}\text { subgroup IB } \\
\qquad(n=45)\end{array}$ & $\begin{array}{l}\text { subgroup IIA } \\
(n=48)\end{array}$ & $\begin{array}{l}\text { subgroup IIB } \\
\quad(n=39)\end{array}$ & $\begin{array}{l}\text { subgroup IIIA } \\
(n=36)\end{array}$ & $\begin{array}{l}\text { subgroup IIIB } \\
\quad(n=32)\end{array}$ & \\
\hline A large number of epithelial cells & $12(24.5)^{x}$ & $24(53.3)^{*}$ & $8(16.7)^{x}$ & $16(41.0)^{*}$ & $6(16.7)^{x}$ & $10(31.2)^{*}$ & $8(16.0)$ \\
\hline \multicolumn{8}{|c|}{ Leukocytes } \\
\hline single & $11(22.4)^{x}$ & $3(6.7)$ & $12(25.0)^{\times}$ & $4(10.6)$ & $10(27.8)$ & $3(9.4)$ & $8(16.0)$ \\
\hline up to 10 in sight & $38(77.6)^{x}$ & $12(26.7)^{*}$ & $36(75.0)^{x}$ & $16(41.0)$ & $26(72.2)$ & $20(62.5)$ & $33(66.0)$ \\
\hline $1 / 2$ fields of view & - & $24(53.3)^{*}$ & - & $14(35.9)$ & - & $7(21.9)$ & $7(14.0)$ \\
\hline the whole field of view & - & $6(13.3)$ & - & $5(12.8)$ & - & $2(6.5)$ & $2(4.0)$ \\
\hline Gram-positive rods & $39(79.6)$ & $28(62.2)$ & $41(85.4)$ & $19(48.7)$ & $29(80.6)$ & $21(65.6)$ & $43(86.0)$ \\
\hline Gram-negative rods & $19(38.8)$ & $21(46.7)^{*}$ & $14(29.2)$ & $17(43.6)^{*}$ & $6(16.7)$ & $7(21.9)$ & $13(26.0)$ \\
\hline Gram-positive cocci & $15(30.6)^{*}$ & $11(24.4)$ & $16(33.3)^{*}$ & $9(23.1)$ & $10(27.8)$ & $5(15.6)$ & $8(16.0)$ \\
\hline Candida fungi & $11(22.4)^{\times}$ & $22(48.9)^{*}$ & $10(20.8)^{x}$ & $17(43.6)^{*}$ & $4(11.1)$ & $6(18.8)$ & $11(22.0)$ \\
\hline Mixed flora & $41(83.7)^{*}$ & $39(86.7)^{*}$ & $46(95.8)^{*}$ & $39(100.0)^{*}$ & $31(86.1)^{*}$ & $30(93.8) *$ & $23(46.0)$ \\
\hline Positive amine test & - & $13(28.9)^{*}$ & - & $8(20.5)$ & - & $4(12.5)$ & $4(8.0)$ \\
\hline
\end{tabular}




\section{ВАГІТНІСТЬ | ПОЛОГИ}

Table 2. Qualitative indicators of opportunistic aerobic and anaerobic microorganisms of the biocenosis of the genital tract in the study groups, $\mathrm{n}(\%)$

\begin{tabular}{|c|c|c|c|c|c|c|c|}
\hline \multirow{3}{*}{ Flora } & \multicolumn{6}{|c|}{ Main group $(n=249$ ) } & \multirow{3}{*}{$\begin{array}{l}\text { Control group } \\
(\mathrm{n}=50)\end{array}$} \\
\hline & \multicolumn{2}{|c|}{ I group $(n=94)$} & \multicolumn{2}{|c|}{ II group $(n=87)$} & \multicolumn{2}{|c|}{ III group $(n=68)$} & \\
\hline & $\begin{array}{l}\text { subgroup IA } \\
(n=49)\end{array}$ & $\begin{array}{c}\text { subgroup IB } \\
(n=45)\end{array}$ & $\begin{array}{c}\text { subgroup IIA } \\
(n=48)\end{array}$ & $\begin{array}{c}\text { subgroup IIB } \\
(n=39)\end{array}$ & $\begin{array}{c}\text { subgroup IIIA } \\
(\mathrm{n}=36)\end{array}$ & $\begin{array}{c}\text { subgroup IIIB } \\
\quad(n=32)\end{array}$ & \\
\hline Staphylococcus epidermidis & $16(32.6)$ & $18(40.0)^{*}$ & $12(25.0)$ & $12(30.8)$ & $6(16.7)$ & $5(15.6)$ & $11(22.0)$ \\
\hline Enterococcus feacalis & $12(24.5)^{\times *}$ & $20(44.4)^{*}$ & $5(10.4)^{x}$ & $8(20.5)$ & $3(8.3)$ & $4(12.5)$ & $6(12.0)$ \\
\hline Streptococcus viridans & - & $3(6.7)$ & - & $2(5.1)$ & - & $1(3.2)$ & - \\
\hline Escherichia coli & $10(20.4)^{x}$ & $19(42.2)^{*}$ & $4(8.3)$ & $8(20.5)$ & $5(13.9)$ & $6(18.8)$ & $7(14.0)$ \\
\hline Bacteroides fragilis & $4(8.2)^{x}$ & $10(22.2)^{*}$ & $2(4.2)$ & $5(12.8)$ & $2(5.6)$ & $2(6.2)$ & $3(6.0)$ \\
\hline Gardnerella vaginalis & - & $13(28.9)$ & - & $8(20.5)^{*}$ & - & $4(12.5)$ & $4(8.0)$ \\
\hline Atopobium vaginae & - & $3(6.7)$ & - & $3(7.6)$ & $2(5.6)$ & $3(9.4)$ & $2(4.0)$ \\
\hline Candida albicans & $11(22.4)^{x}$ & $22(48.9)^{*}$ & $10(20.8)^{x}$ & $17(43.6)^{*}$ & $4(11.1)$ & $6(18.8)$ & $11(22.0)$ \\
\hline Peptococcus anaerobic & $2(4.1)$ & $5(11.1)$ & $4(8.3)$ & $4(10.2)$ & - & $2(6.2)$ & $3(6.0)$ \\
\hline Peptostreptococcus anaerobic & - & $4(8.9)$ & - & $3(7.6)$ & - & - & - \\
\hline Prevotella bivia & $3(6.1)$ & $6(13.3)$ & $2(4.2)$ & $5(12.8)$ & $2(5.6)$ & $2(6.2)$ & $4(8.0)$ \\
\hline Fusobacterium nucleatum & - & $3(6.7)$ & - & $2(5.1)$ & - & & - \\
\hline Lactobacillus spp. & $29(59.2)^{\times *}$ & $13(28.9)^{*}$ & $30(62.5)^{\times}$ & $14(35.9)^{*}$ & $26(72.2)^{\times}$ & $18(56.3)^{*}$ & $37(74.0)$ \\
\hline
\end{tabular}

* statistically significant differences compared with the control group $(p<0.05)$

× statistically significant differences between $A$ and B subgroups

Table 3. Quantitative indicators of opportunistic aerobic and anaerobic microorganisms of the biocenosis of the genital tract in in the study groups ( $\mathrm{Lg} \mathrm{M} \pm \mathrm{m}$, $\mathrm{CFU} / \mathrm{ml})$

\begin{tabular}{|c|c|c|c|c|c|c|c|}
\hline \multirow{3}{*}{ Flora } & \multicolumn{6}{|c|}{ Main group $(\mathrm{n}=249$ ) } & \multirow{3}{*}{$\begin{array}{l}\text { Control group } \\
(n=50)\end{array}$} \\
\hline & \multicolumn{2}{|c|}{ I group $(n=94)$} & \multicolumn{2}{|c|}{ II group $(\mathrm{n}=87)$} & \multicolumn{2}{|c|}{ III group $(n=68)$} & \\
\hline & $\begin{array}{c}\text { subgroup IA } \\
(n=49)\end{array}$ & $\begin{array}{l}\text { subgroup IB } \\
(\mathrm{n}=45)\end{array}$ & $\begin{array}{c}\text { subgroup IIA } \\
\quad(n=48)\end{array}$ & $\begin{array}{c}\text { subgroup IIB } \\
(\mathrm{n}=39)\end{array}$ & $\begin{array}{c}\text { subgroup IIIA } \\
\quad(n=36)\end{array}$ & $\begin{array}{c}\text { subgroup IIIB } \\
\quad(n=32)\end{array}$ & \\
\hline Staphylococcus epidermidis & $3.4 \pm 0.2^{x}$ & $4.52 \pm 0.3^{*}$ & $3.2 \pm 0.3^{x}$ & $4.21 \pm 0.4^{*}$ & $3.1 \pm 0.4$ & $3.3 \pm 0.4$ & $3.0 \pm 0.6$ \\
\hline Enterococcus feacalis & $3.1 \pm 0.4^{x}$ & $4.61 \pm 0.3^{*}$ & $3.4 \pm 0.3^{x}$ & $4.52 \pm 0.4^{*}$ & $2.1 \pm 0.2$ & $3.0 \pm 0.5$ & $3.23 \pm 0.6$ \\
\hline Streptococcus viridans & - & $3.25 \pm 0.8$ & - & $2.9 \pm 0.4$ & - & $2.4 \pm 0.3$ & - \\
\hline Escherichia coli & $2.5 \pm 0.3^{x}$ & $4.0 \pm 0.27 *$ & $2.3 \pm 0.3^{x}$ & $3.6 \pm 0.24$ & $2.0 \pm 0.3$ & $2.61 \pm 0.21$ & $2.86 \pm 0.3$ \\
\hline Bacteroides fragilis & $2.5 \pm 0.4^{x}$ & $4.57 \pm 0.40^{*}$ & $2.0 \pm 0.3^{x}$ & $4.0 \pm 0.34^{*}$ & $2.0 \pm 0.4$ & $2.1 \pm 0.35$ & $2.5 \pm 0.7$ \\
\hline Atopobium vaginae & - & $4.33 \pm 0.46^{*}$ & - & $3.7 \pm 0.3$ & $2.0 \pm 0.3$ & $2.3 \pm 0.33$ & $2.5 \pm 0.7$ \\
\hline Candida albicans & $3.1 \pm 0.2^{x}$ & $6.2 \pm 0.3^{*}$ & $3.0 \pm 0.3^{x}$ & $5.6 \pm 0.4^{*}$ & $3.2 \pm 0.4^{x}$ & $4.1 \pm 0.3$ & $3.8 \pm 0.3$ \\
\hline Peptococcus anaerobic & $3.0 \pm 0.4$ & $4.32 \pm 0.58 *$ & $2.5 \pm 0.3$ & $4.06 \pm 0.41$ & - & $2.33 \pm 0.3$ & $2.52 \pm 0.3$ \\
\hline Peptostreptococcus anaerobic & $3.6 \pm 0.4$ & $6.12 \pm 0.42$ & - & $5.7 \pm 0.36$ & - & - & - \\
\hline Prevotella bivia & $3.0 \pm 0.2$ & $3.84 \pm 0.26^{*}$ & $2.6 \pm 0.4$ & $3.44 \pm 0.31$ & $2.0 \pm 0.3$ & $2.5 \pm 0.37$ & $2.6 \pm 0.3$ \\
\hline Fusobacterium nucleatum & $3.2 \pm 0.3$ & $3.9 \pm 0.35$ & - & $3.6 \pm 0.41$ & - & - & - \\
\hline Lactobacillus spp. & $4.34 \pm 0.2^{x}$ & $3.40 \pm 0.42 *$ & $4.54 \pm 0.3^{x}$ & $3.51 \pm 0.4$ & $4.54 \pm 0.39$ & $4.34 \pm 0.41$ & $4.94 \pm 0.3$ \\
\hline
\end{tabular}

${ }^{*}$ statistically significant differences compared with the control group $(p<0.05)$

${ }^{\times}$statistically significant differences between $A$ and B subgroups

provides stabilization of vaginal $\mathrm{pH}$ at the physiological level, which corresponds to the normocenosis and contributes to a significant increase in Lactobacillus spp. within the physiological norm with a significant decrease of Candida albicans concentration in the biotope, as well as opportunistic pathogens of aerobic and anaerobic origin. This is provides conditions for prolongation of pregnancy in women after ART treatment cycles.

\section{Conflict of interest}

The authors report no personal, scientific and financial conflicts of interests. 


\section{REFERENCES/ЛITEPATYPA}

1. Жук, С.И.

Пероральные пробиотики - залог успешной

беременности / Жук, С.И., Ус, И.В., Шляхтина, А.А. //

Здоровье женщины. - 2016. - № 10 (116). - С. 55-56.

Zhuk, S.I., Us, I.V., Shljahtina A.A.

"Oral probiotics are the key to a successful pregnancy." Health of

Women 10.116 (2016): 55-56.

2. Жук, С.И.

Управление биотопами женщины - новые подходы /

Жук, С.И., Шляхтина, А.А. // Здоровье женщины. - 2018. -

№ 6. - C. 34-36.

Zhuk, S.I., Shljahtina, A.A.

"Women's biotope management - new approaches." Health of Women 5.132 (2018): 34-36.

3. Лахтин, М.B.

Мультиузловая концепция микробиоценоза биотопа

человека / Лахтин, М.В., Лахтин, В.М., Байракова,

А.Л. [и др.] // Клиническая лабораторная диагностика. -

2014. - № 9. - C.83.

Lahtin, M.V., Lahtin, V.M., Bajrakova, A.L., et al.

"Multi-node concept of human biotope microbiocenosis."

Clinical and laboratory diagnostics 59.9 (2014): 83.

4. Наказ Міністерства охорони здоров'я України № 417

від 15.07.2011р.

«Методичні рекомендації щодо надання амбулаторної

акушерсько-гінекологічної допомоги».

Order of the Ministry of Health of Ukraine No. 417

of 15.07.2011

"Methodological recommendations for providing outpatient

obstetric and gynecological care".

5. Наказ Міністерства охорони здоров'я України № 787

від 09.09.2013 р.

«Порядок застосування допоміжних репродуктивних

технологій в Україні».

Order of the Ministry of Health of Ukraine No. 787

of 09.09.2013

"Procedure for the use of assisted reproductive technologies in Ukraine".

6. Наказ Міністерства охорони здоров'я України № 234

від 10.05.2007

«Про організацію профілактики внутрішньолікарняних

інфекцій в акушерських стаціонарах».

Order of the Ministry of Health of Ukraine No. 234

of 10.05.2007

"On the organization of prevention of nosocomial infections in

obstetric hospitals".

7. Наказ Міністерства охорони здоров'я України № 906

від 27.12.2006р.

«Перинатальні інфекції».

Order of the Ministry of Health of Ukraine №. 906

of 27.12.2006

"Perinatal infections".

8. Маркін, Л.Б.

Комплексна терапія рецидивуючого хронічного

генітального хламідіозу / Маркін, Л.Б., Шахова,

0.В., Попович, А.І. // Актуальні питання педіатрії,

акушерства та гінекології. - 2012. - № 2. - С. 1-6.

Markin, L.B., Shahova, O.V., Popovych, A.I.

"Complex therapy of recurrent chronic genital chlamydia."

Actual Problems of Pediatrics, Obstetrics and Gynecology

2(2012): 1-6.

9. Нагорная, В.Ф.

pH влагалищного секрета в оценке влагалищной микробиоты во время беременности / Нагорная, В.Ф.,

Москаленко, Т.Я., Гриценко, А.А. // Здоровье женщины. 2015. - № 6. - C. 90-93.
Nagornaja, V.F., Moskalenko, T.J., Gricenko A.A.

"The pH of the vaginal secretion in the assessment of the vaginal microbiota during pregnancy." Health of Women 6 (2015): 90-93.

\section{0. Подольский, В.В.}

Лікувально-профілактичні заходи, спрямовані на корекцію мікробіоценозу урогенітальних органів у жінок

фертильного віку, мешканок сільськогосподарського району України / Подольский, В.В., Каграманян, А.Л. // Неонатологія, хірургія та перинатальна медицина. 2015. - № 5 (2). - C. 66-71.

Podol'skyj, V.V., Kagramanjan A.L.

"Therapeutic and preventive measures aimed at correcting the microbiocenosis of urogenital organs in women of fertile age, residents of the agricultural region of Ukraine." Neonatology,

Surgery, and Perinatal Medicine 5.2 (2015): 66-71.

11. Прилепская, В.H.

Микробиоценоз влагалища и полиморфизм генов цитокинов как маркер здоровья женщины (обзор литературы) / Прилепская, В.Н., Летуновская, А.Б., Донников, А.Е. // Гинекология. - 2015. - № 17 (2). C. 4-13.

Prilepskaja, V.N., Letunovskaja, A.B., Donnikov, A.E. "Vaginal microbiocenosis and cytokine gene polymorphism as a marker of a woman's health (literature review)." Gynecology 17.2 (2015): 4-13.

12. Сейтханова, Б.Т.

Микробиоценоз влагалища и кишечника беременных женщин / Сейтханова, Б.Т., Шапамбаев, 3.3., Олжаева, Р.Р., Калменова, П.Е. // Наука и здравоохранение. - 2014. № 1. - C. 70-71.

Sejthanova, B.T., Shapambaev, Z.Z., Olzhaeva, R.R., Kalmenova, P.E.

"Microbiocenosis of the vagina and intestines of pregnant women." Science and Healthcare 1 (2014): 70-71.

13. Синякова, А.А.

Современные представления о микробиоценозе влагалища и его влиянии на исходы беременности / Синякова, А.А. // Журнал акушерства и женских болезней. - 2017. - Т. 66. - №6. - С. 89-100. Sinjakova, A.A.

"Modern ideas about the vaginal microbiocenosis and its impact on pregnancy outcomes." Journal of Obstetrics and Women's Diseases 66.6 (2017): 89-100.

14. Синякова, А.А.

Микробиоценоз влагалища в первом триместре

беременности у женщин с невынашиванием

беременности в анамнезе / Синякова, А.А.,

Шипицына, Е.В., Рыбина, Е.В. [и др.] // Журнал акушерства

и женских болезней. - 2016. - Т. 65. - № 4. - С. 44-49.

Sinjakova, A.A., Shipicyna, E.V., Rybina, E.V., et al.

"Vaginal microbiocenosis in the first trimester of pregnancy

in women with a history of miscarriage." Journal of Obstetrics and Women's Diseases 65.4 (2016): 44-9.

D0l: 10.17816/JOWD65444-49

15. Туманова, Л.Е.

Микробиоценоз влагалища у беременных с различными видами бесплодия в анамнезе / Туманова, Л.Е., Коломиец, Е.В. // Украинский журнал Перинатология и Педиатрия. - 2020. - № 2 (82). - С. 68-75.

Tumanova, L.E., Kolomiec, E.V.

"Vaginal microbiocenosis in pregnant women with a history of various types of infertility." Ukrainian Journal of Perinatology and Pediatrics 2.82 (2020): 68-75.

DOI: 10.15574/PP.2020.82.68

16. Хрянин, А.А.

Хламидийная инфекция: от науки кпрактике /

Хрянин, А.А., Решетников, О.В. - Киев: 000 Тетрис-принт, 2012. -180 C.
Hrjanin, A.A., Reshetnikov, O.V.

"Chlamydia infection: from science to practice." Kyiv: Tetris-print (2012): $180 \mathrm{p}$

17. Шалепо, К.В.

Оценка современных методов лабораторной диагностики бактериального вагиноза / Шалепо, К.В. // Журнал акушерских и женских болезней. - 2014. - 63 (1). C. 26-32.

Shalepo, K.V.

"Evaluation of modern methods of laboratory diagnostics of bacterial vaginosis." Journal of Obstetric and Women's Diseases 63. 1 (2014): 26-32.

18. Anderson, B.L., Cu-Uvin, S., Raker, C.A., et al. "Subtle perturbations of genital microflora alter mucosal immunity among low-risk pregnant women." Acta Obstet Gynecol Scand 90.5 (2011): 510.

19. Freitas, A.C., Chaban, B., Bocking, A.

"The vaginal microbiome of pregnant women is less rich and diverse, with lower prevalence of Mollicutes, compared to non-pregnant women." Scientific Reports 7 (2017). Article number: 9212.

20. Kovachev, $S$.

"Defence factors of vaginal lactobacilli." Critical Reviews in Microbiology 44.1 (2018): 31-39.

21. Macklaim, J.M., Gloor, G.B., Anukam, K.C., et al.

"At the crossroads of vaginal health and disease, the genome sequence of Lactobacillus iners AB-1." Proc Natl Acad Sci USA 108.1 (2011): 4688-4695. D0l: 10.1073/pnas. 1000086107

22. Petricevic, L., Domig, K., Nierscher, F.J., et al.

"Characterisation of the vaginal Lactobacillus microbiota associated with preterm delivery." Sci Rep 4 (2014): 51362. DOl: 10.1038/srep05136

23. Rampersaud, R., Planet, P.J., Randis, T.M., et al.

"Inerolysin, a cholesterol-dependent cytolysin produced by

Lactobacillus iners." J Bacteriol 193.5 (2011): 1034-41.

24. Roberts, C.L., Morris, J.M., Rickard, K.R., et al.

"Protocol for a randomised controlled trial of treatment of asymptomatic candidiasis for the prevention of preterm birth." BMC pregnancy and childbirth 11 (2011): 19.

25. Sherrard, J., Donders, G., White, D., Jensen, J.S.

"European (IUSTI/WHO) guideline on the management of vaginal discharge, 2011." International journal of STD \& AIDS 22.8 (2011): 421-9.

26. Zodzika, J., Rezeberga, D., Jermakova, I., et al. "Factors related to elevated vaginal pH in the first trimester of pregnancy." Acta obstetricia et gynecologica Scandinavica 90.1 (2011): $41-6$. 
L.M. Vygivska, PhD, assistant professor, Obstetrics and Gynecology Department No. 3, Bogomolets National Medical University, Kyiv V.0. Beniuk, MD, professor, head of the Obstetrics and Gynecology Department No. 3, Bogomolets National Medical University, Kyiv I.V. Maidannyk, PhD, assistant professor, Obstetrics and Gynecology Department No. 3, Bogomolets National Medical University, Kyiv I.A. Usevych, PhD, assistant professor, Obstetrics and Gynecology Department No. 3, Bogomolets National Medical University, Kyiv L.D. Lastovetska, PhD, assistant professor, Obstetrics and Gynecology Department №. 3, Bogomolets National Medical University, Kyiv Y.G. Drupp, PhD, assistant professor, Obstetrics and Gynecology Department No. 3, Bogomolets National Medical University, Kyiv

V.V. Kurochka, PhD, assistant, Obstetrics and Gynecology Department No. 3, Bogomolets National Medical University, Kyiv

Research objective: to determine the role and effectiveness of the proposed therapeutic and prophylactic complex in the correction of vaginal biocenosis disorders in the dynamics of pregnancy in pregnant women after assisted reproductive technologies (ART) to improve the tactics of antenatal observation and prevention of obstetric and perinatal complications.

Materials and methods. 299 pregnant women were examined: the main group included 249 women with pregnancy after ART, the control group consisted of 50 pregnant women with spontaneous pregnancy.

Therapeutic and prophylactic measures for pregnant women after ART included: micronized progesterone, magnesium oxide, folic acid, L-arginine aspartate, $\omega$-3-polyunsaturated fatty acids, long-term psychological correction (on the eve of the ART program, at 8-10 weeks, 16-18 weeks and 28-30 weeks of pregnancy). The drug for antibiotic therapy for local sanitation of the genital tract was chosen taking into account the sensitivity to antibiotics of certain microbial associates and was prescribed for $7-10$ days.

At the second stage of sanitation of the genital tract probiotics were prescribed under the control of pH-metry to maintain the acidic environment of the vaginal contents, colonize the vagina and the vaginal part of the cervix with lactobacilli.

Results. There was a significant decrease in the proportion of women with a large number of epithelial cells in the main groups, which are a sign of alterative inflammation, and this is coincides with a similar indicator in the control group. Women with moderate leukocyte count and mixed Gram-negative microflora prevailed in IB, IIB and IIIB subgroup, who received conventional therapy. There was no significant difference in IIIA and IIIB subgroups. In the vaginal biocenosis significantly increased the Lactobacillus spp. content against the background of probiotics with local and general action in IA, IIA and IIIA subgroups. The average Lactobacillus spp. concentration was significantly different from the average indicators of subgroups receiving conventional therapy for vaginal sanitation, with a significant decrease in the biocenosis of aerobic and anaerobic microorganisms and Candida albicans, which indicates the effectiveness of the proposed two-stage treatment.

Conclusions. The proposed improved two-stage sanitation of the genital tract with a selective probiotic against the background of long-term progesterone and magnesium support ensures the stabilization of the vaginal pH at the physiological level corresponding to the normocenosis, and contributes to a significant increase in Lactobacillus spp. within the physiological norm with a significant decrease of Candida albicans concentration in the biotope, as well as opportunistic pathogens of aerobic and anaerobic origin. This is provides conditions for the prolongation of pregnancy in women after ART treatment cycles.

Keywords: assisted reproductive technologies, vaginal biocenosis, progesterone, pH, probiotics.

\section{МОЖЛИВОСТІ КОРЕКЦІЇ ПІХВОВОГО БІОТОПУ У ВАГІТНИХ ПІСЛЯ ЗАСТОСУВАННЯ ДОПОМІЖНИХ РЕПРОДУКТИВНИХ ТЕХНОЛОГІЙ}

Л.М. Вигівська, к. мед. Н., доцент кафедри акушерства і гінекології № 3 Нму ім. 0.0. Богомольця, м. Київ

В.О. Бенюк, д. мед. Н., професор, зав. кафедри акушерства і гінекології № 3 Нму ім. 0.0. Богомольця, м. Київ

І.В. Майданник, К. мед. Н., доцент кафедри акушерства і гінекології № 3 НМУ ім. 0.0. Богомольця, м. Київ

І.А. Усевич, к. мед. н., доцент кафедри акушерства і гінекології № 3 НМУ ім. 0.0. Богомольця, м. Київ

Л.Д. Ластовецька, к. мед. н., доцент кафедри акушерства і гінекології № 3 НМУ ім. 0.0. Богомольця, м. Київ

Ю.Г. Друпп, к. мед. н., доцент кафедри акушерства і гінекології № 3 Нму ім. 0.0. Богомольця, м. Київ

В.В. Курочка, к. мед. Н., асистент кафедри акушерства і гінекології № 3 НмУ ім. 0.0. Богомольця, м. Київ

Мета дослідження. Визначити роль та ефективність запропонованого лікувально-профілактичного комплексу при корекції порушень біоценозу піхви в динаміці вагітності у вагітних після допоміжних репродуктивних технологій (ДРТ) для вдосконалення тактики антенатального спостереження та профілактики акушерських і перинатальних ускладнень.

Матеріали та методи. Обстежено 299 вагітних: до основної групи увійшли 249 жінок, вагітність яких настала в результаті застосування ДРТ, контрольну групу становили 50 жінок зі спонтанним настанням вагітності. Комплекс лікувально-профілактичних заходів для вагітних після ДРТ включав: мікронізований прогестерон, магнію оксид, фолієву кислоту, L-аргініну аспартат, $\omega$-3-поліненасичені жирні кислоти, тривалу психологічну корекцію (напередодні програми ДРТ, на 8-10 тижні, 16-18 тижні та 28-30 тижні вагітності). Препарат для антибактеріальної терапії для місцевої санації статевих шляхів обирали з урахуванням чутливості до антибіотиків визначених мікробних асоціантів і призначали на 7-10 днів.

Для підтримки кислого середовища піхвового вмісту, колонізації піхви й піхвової частини шийки матки лактобактеріями на II етапі санації статевих шляхів під контролем рН-метрії призначали пробіотики. Результати. Серед вагітних основних груп відмічено достовірне зниження питомої ваги осіб із великою кількістю епітеліальних клітин, які є ознакою альтеративного запалення, що збігається з аналогічним показником у групі контролю. Серед вагітних підгруп ІБ, ІІБ і ІІБ, які отримували загальноприйняту терапію, переважали жінки з помірним вмістом лейкоцитів і змішаною грамнегативною мікрофлорою. У підгрупах ||ІА і ІІББ достовірної різниці не відмічено.

На тлі застосування пробіотиків локальної та загальної дії в динаміці лікування жінок підгруп IA, IIA і IIIA у піхвовому біоценозі достовірно збільшився вміст Laсtobacillus spp., середня концентрація яких вірогідно відрізнялася від середніх показників підгруп, які отримували загальноприйняту терапію для санації піхви, при достовірному зменшенні концентрації в біоценозі мікроорганізмів аеробного й анаеробного походження та грибів Candida albicans, що свідчить про ефективність запропонованого двоетапного лікування.

Висновки. Запропонована вдосконалена двоетапна санація статевих шляхів селективним пробіотиком на тлі тривалої прогестеронової та магнієвої підтримки забезпечує стабілізацію рН піхви на фізіологічному рівні, що відповідає нормоценозу і сприяє достовірному зростанню концентрації Lactobacillus spp. у межах фізіологічної норми при достовірному зменшенні концентрації Саndida albicans, а також умовно-патогенних мікроорганізмів аеробного й анаеробного походження, що забезпечує умови для пролонгації вагітності у жінок після лікувальних циклів ДРТ.

Ключові слова: допоміжні репродуктивні технології, біоценоз піхви, прогестерон, рН, пробіотики.

\section{ВОЗМОЖНОСТИ КОРРЕКЦИИ ВЛАГАЛИЩНОГО БИОТОПА У БЕРЕМЕННЫХПОСЛЕ ПРИМЕНЕНИЯ ВСПОМОГАТЕЛЬНЫХ РЕПРОДУКТИВНЫХ ТЕХНОЛОГИЙ}

Л.Н. Выговская, к. мед. н., доцент кафедры акушерства и гинекологии № 3 Нму им. А.А. Богомольца, г. Киев

В.А. Бенюк, Д. мед. Н., профессор, зав. кафедрой акушерства и гинекологии № 3 НМУ им. А.А. Богомольца, г. Киев

И.В. Майданник, к. мед. Н., доцент кафедры акушерства и гинекологии № 3 НМУ им. А.А. Богомольца, г. Киев

И.А. Усевич, к. мед. н., доцент кафедры акушерства и гинекологии № 3 НМУ им. А.А. Богомольца, г. Киев.

Л.Д. Ластовецкая, к. мед. Н., доцент кафедры акушерства и гинекологии № 3 НМУ им. А.А. Богомольца, г. Киев

Ю.Г. Друпп, к. мед. Н., доцент кафедры акушерства и гинекологии № 3 НмУ им. А.А. Богомольца, г. Киев

В.В. Курочка, к. мед. Н., ассистент кафедры акушерства и гинекологии № 3 НМУ им. А.А. Богомольца, г. Киев

Цель исследования: определить роль и эффективность предложенного лечебно-профилактического комплекса в коррекции нарушений биоценоза влагалища в динамике беременности у беременных после вспомогательных репродуктивных технологий (ВРТ) для совершенствования тактики антенатального наблюдения и профилактики акушерских и перинатальных осложнений.

Материалы и методы. Обследовано 299 беременных: в основную группу вошли 249 женщин, беременность которых наступила в результате применения ВРТ, контрольную группу составили 50 женщин со спонтанным наступлением беременности.

Комплекс лечебно-профилактических мероприятий для беременных после ВРТ включал: микронизированный прогестерон, магния оксид, фолиевую кислоту, L-аргинина аспартат, (--3-полиненасыщенные жирные кислоты, длительную психологическую коррекцию (накануне программы ВРТ, на 8-10 неделе, 16-18 неделе и 28-30 неделе беременности). Препарат для антибактериальной терапии для местной санации половых путей выбирали с учетом чувствительности к антибиотикам определенных микробных ассоциантов и назначали на 7-10 дней.

Для поддержания кислой среды влагалищного содержимого, колонизации влагалища и влагалищной части шейки матки лактобактериями на втором этапе санации половых путей под контролем рН-метрии назначали пробиотики.

Результаты. Среди беременных основных групп отмечали достоверное снижение удельного веса лиц с большим количеством эпителиальных клеток, которые являются признаком альтеративного воспаления, что совпадает с аналогичным показателем в группе контроля. Среди беременных подгрупп ІБ, ІІБ и ІІБ, получавших общепринятую терапию, преобладали женщины сумеренным содержанием лейкоцитов и смешанной грамотрицательной микрофлорой. В подгруппах ІІІА и ІІББ достоверной разницы не отмечено.

На фоне применения пробиотиков локального и общего действия в динамике лечения женщин подгрупп IA, IIA и IIIA во влагалищном биоценозе достоверно увеличилось содержание Lactobacillus spp., средняя концентрация которых достоверно отличалась от средних показателей подгрупп, получавших общепринятую терапию для санации влагалища, при достоверном уменьшении концентрации в биоценозе микроорганизмов аэробного и анаэробного происхождения и грибов Candida albicans, что свидетельствует об эффективности предложенного двухэтапного лечения.

Выводы. Предложенная усовершенствованная двухэтапная санация половых путей селективным пробиотиком на фоне длительной прогестероновой и магниевой поддержки обеспечивает стабилизацию рН влагалища на физиологическом уровне, соответствующем нормоценозу, и способствует достоверному росту концентрации Lactobacillus spp. в пределах физиологической нормы при достоверном уменьшении концентрации Сапdida albicans, а также условно-патогенных микроорганизмов аэробного и анаэробного происхождения, что обеспечивает условия для пролонгации беременности уженщин после лечебных циклов ВРТ. 